
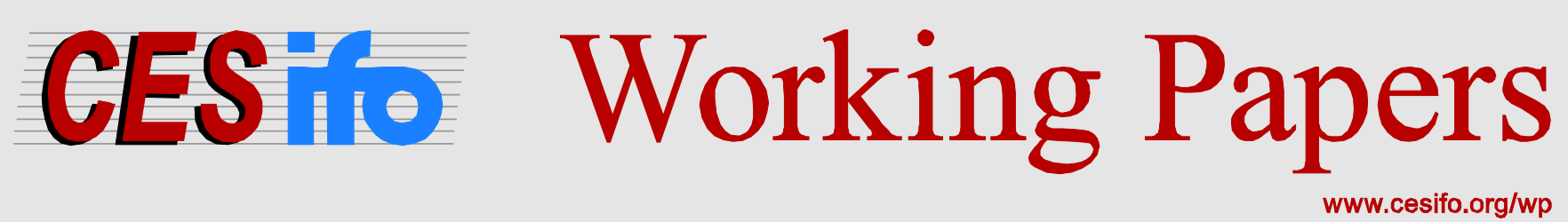

\title{
Does Income Inequality Lead to Terrorism?
}

\author{
Tim Krieger \\ Daniel Meierrieks
}

CESIFO WORKING PAPER NO. 5821

CATEgory 2: Public CHOICE

MARCH 2016

An electronic version of the paper may be downloaded

- from the SSRN website:

- from the RePEc website:

- from the CESifo website:

WwW.SSRN.com

www.RePEc.org

www.CESifo-group.org/wp 


\title{
Does Income Inequality Lead to Terrorism?
}

\begin{abstract}
We analyze the effect of income inequality on terrorism for a sample of 114 countries between 1985 and 2012. We provide evidence, robust to various methodological changes (e.g., different dependent variables, instrumental-variable approaches), that higher levels of income inequality are associated with more terrorism. Consistent with relative deprivation theory, we argue that this effect is a direct consequence of frustration over the distribution of income within a society, resulting in terrorism to voice dissent and achieve a redistribution of wealth. Furthermore, we provide evidence of an indirect effect of inequality on terrorism, where inequality may also contribute to terrorism by leading to weaker institutions. Finally, we show that redistributional efforts can be effective in reducing inequality and, consequently, terrorist activity.
\end{abstract}

JEL-Codes: D740, I380, O150, C360.

Keywords: income inequality, terrorism, Gini coefficient, relative deprivation, redistribution.

\author{
Tim Krieger* \\ University of Freiburg \\ Wilhelmsstraße $1 b$ \\ Germany - 79098 Freiburg \\ tim.krieger@vwl.uni-freiburg.de
}

\author{
Daniel Meierrieks \\ University of Freiburg \\ Wilhelmsstraße $1 b$ \\ Germany - 79098 Freiburg \\ daniel.meierrieks@vwl.uni-freiburg.de
}

*corresponding author 


\section{Introduction}

Terrorism may produce substantial social and economic costs for affected countries not only by destroying lives and property but also by, e.g., reducing investment activity (e.g., Crain and Crain, 2006; Abadie and Gardeazabal, 2008) and trade (e.g., Nitsch and Schumacher, 2004) as well as influencing financial markets (e.g., Melnick and Eldor, 2010) and government spending (e.g., Gupta et al., 2004) in ways that impair economic activity. Consequently, terrorism and the associated political instability may be harmful to economic growth (Alesina and Perotti, 1996; Gupta et al., 2004; Crain and Crain, 2006; Sandler and Enders, 2008).

To reduce terrorism and with it its socio-economic costs, it is necessary to understand in which social conditions terrorism is rooted. Here, influential voices have repeatedly related income inequality to the emergence of terrorism and violence. For instance, in 2013 Pope Francis stated that "until exclusion and inequality in society and between peoples are reversed, it will be impossible to eliminate violence [...].”1

In light of this discussion we study the effect of income inequality on terrorism. We contribute to the sparse literature on the nexus between inequality and terrorism in several ways, providing - to the best of our knowledge - the first comprehensive study of the inequalityterrorism nexus. First, previous empirical analyses studying the political and economic consequences of inequality have been criticized on grounds of using inequality data of poor quality (e.g., Easterly, 2007). To overcome this issue, we use more consistent income inequality data drawn from a recently published income inequality dataset developed by Solt (2009), the Standardized World Income Inequality Database. Second, we consider the role of endogeneity in the inequality-terrorism nexus, where endogeneity may stem from simultaneity due to the distributional consequences of terrorism. Third, we provide both an in-depth theoretical discussion and empirical analysis of the transmission channels from income inequality to terrorism. This ought to strengthen our understanding of how the inequality-terrorism nexus actually works. Finally, we analyze how redistribution (i.e., the reduction of income inequality through taxation and other policies) affects terrorism. Here, we add to a small body of recent research (Burgoon, 2006; Krieger and Meierrieks, 2010) emphasizing the beneficial role of functioning social welfare systems in reducing terrorism.

\footnotetext{
${ }^{1}$ See http://tinyurl.com/qclzcn6.
} 
To preview our empirical findings, for a sample of 114 countries for the 1985-2012 period we indeed show that higher levels of income inequality result in more terrorist activity. This effect is also quantitatively substantive and holds when endogeneity is accounted for. Our main finding of a terror-augmenting effect of income inequality is also robust to various methodological changes (different dependent variables, different estimation methods etc.). With respect to the transmission channels from inequality to terrorism, our analysis suggests that income inequality may especially promote terrorism by directly fueling social frustration due to relative deprivation and, indirectly, by contributing to the erosion of institutions, e.g., by undermining the rule of law. Finally, we show that redistribution (i.e., a reduction of income inequality) is associated with less terrorism. Our empirical analysis thus suggests that policymakers ought to take seriously the inflammatory effects of inequality, but may be able to counter them through tax and welfare policies geared towards greater redistribution and income equality.

The remainder of this paper is organized as follows. In Section 2 we discuss the theoretical and empirical literature on the effect of inequality on terrorism. In Section 3 we introduce the data and econometric methods to empirically study the inequality-terrorism nexus. Our main empirical results and further empirical extensions are reported in Section 4. Section 5 concludes.

\section{Inequality and Terrorism: Theory and Evidence}

In this section we discuss several theoretical pathways through which income inequality may be conducive to terrorism. First, we introduce the ideas of relative deprivation theory which postulates a direct link from inequality to terrorism. Second, we discuss indirect linkages between inequality and terrorism, where inequality may lead to terrorism via its deleterious effect on socio-economic development and the quality of institutions. Third, we discuss the sparse evidence on the inequality-terrorism nexus and our additions to this body of empirical research.

Relative Deprivation Theory. A direct link between inequality and terrorism follows from the so-called relative deprivation theory. First, this theory posits that members of society evaluate their economic position relative to reference groups in society (Yitzhaki, 1979, 1982). Second, it argues that members of society develop feelings of discontent and frustration when their economic position compares unfavorably to a reference group (i.e., when they are relatively 
deprived). Third, the theory posits that these feelings matter strongly to participation in collective action. That is, frustration due to relative deprivation may lead to participation in peaceful protests (e.g., demonstrations) but also collective (political) violence (e.g., civil war, revolutions) to counter inequality. Most important to our study, discontent and frustration may also lead to terrorism, where terrorism is employed to voice discontent over the economic status quo and change it in favor of the relatively deprived.

The idea of relative deprivation is already recognized, implicitly, in Adam Smith's seminal book on the Wealth of Nations. Smith (1776: 870) writes:

"By necessaries I understand not only the commodities which are indispensably necessary for the support of life, but whatever the custom of the country renders it indecent for creditable people, even of the lowest order, to be without. A linen shirt, for example, is, strictly speaking, not a necessary of life. The Greeks and Romans lived, I suppose, very comfortably though they had no linen. But in the present times [...] a creditable day-labourer would be ashamed to appear in public without a linen shirt, the want of which would be supposed to denote that disgraceful degree of poverty which, it is presumed, nobody can well fall into without extreme bad conduct. Custom, in the same manner, has rendered leather shoes a necessary of life in England. The poorest creditable person of either sex would be ashamed to appear in public without them.”

In this excerpt, Smith (1776) argues that economic deprivation (here, the lack of a linen shirt or leather shoes) is seen in relation to other members of society and creates frustration (humiliation) among the relatively deprived. Karl Marx makes a similar point, discussing how relative deprivation develops and leads to discontent. He (1848: Para 4) writes:

"A house may be large or small; as long as the neighboring houses are likewise small, it satisfies all social requirement for a residence. But let there arise next to the little house a palace, and the little house shrinks to a hut. The little house now makes it clear that its inmate has no social position at all to maintain, or but a very insignificant one; [...] the occupant of the relatively little house will always find himself more uncomfortable, more dissatisfied, more cramped within his four walls.”

Discontent and frustration due to relative deprivation are ultimately expected to feed the appetite of the-ostensibly_disenfranchised for revolution and political violence. Indeed, MacCulloch (2005) finds that income inequality has a positive impact on the probability that 
individuals have revolutionary preferences. The direct link between the genesis of organized political violence and the frustration and discontent due to relative deprivation is also explicitly stated by Gurr (1970: 12-13):

"The primary causal sequence in political violence is first the development of discontent, second the politicization of that discontent, and finally its actualization in violent action against political objects and actors. Discontent arising from the perception of relative deprivation is the basic, instigating condition for participants in collective violence.”

Or, as put by Alesina and Perotti (1996: 1214):

“A large group of impoverished citizens, facing a small and very rich group of well-off individuals is likely to become dissatisfied with the existing socio-economic status quo and demand radical changes, so that mass violence and illegal seizure of power are more likely than when income distribution is more equitable.”

With respect to the inequality-terrorism nexus, relative deprivation theory suggests that a country's level of income inequality is directly related to its level of terrorist activity. Income inequality breeds frustration due to feelings of relative deprivation; frustration in turn results in terrorism. Societies that see higher levels of economic inequality also see larger parts of society affected by relative deprivation. That is, more income inequality within a society coincides with a larger pool of frustrated "have-nots" and thus a higher the risk of terrorism. Terrorism is used by the frustrated "have-nots" to violently voice discontent, punish the "haves" and challenge (and, possibly, change in their favor) the distribution of economic resources. For one, this notion indeed matches the self-perception of terrorist groups which often portray themselves as fighting for "the poor" or "social justice”. For another, it also corresponds to the political goals and incentives often associated with terrorism. The prospects of a redistribution of wealth (as a political objective of a terrorist group) as well as the forcible capture and exploitation of rents (e.g., from natural resources) that advance one's economic position may offer strong incentives to engage in terrorist activity.

Indirect Linkages. Besides a direct relationship between inequality and terrorism associated with relative deprivation theory, inequality may also magnify certain social conditions that in turn lead to terrorism. These social conditions can be thought of as mediators. Arguing that 
inequality influences these mediators which in turn affect terrorism establishes an indirect effect of inequality on terrorism.

First, inequality may lead to poorer socio-economic outcomes. For example, inequality may constrain the poor's investment decisions in education and health, leading to unfavorable situations in which the poor cannot afford an optimal (sufficiently high) level of education or health (Thorbecke and Charumilind, 2002). A number of studies indeed find that inequality negatively affects education and health at the country-level (e.g., Thorbecke and Charumilind, 2002; Easterly, 2007; Neckerman and Torche, 2007; Wilkinson and Picket, 2007). For instance, Easterly (2007) shows that higher levels of income inequality are associated with lower secondary enrollment rates. What is more, by depressing human capital accumulation (in terms of education and health), income inequality may also reduce overall economic activity (e.g., with respect to domestic investment and economic growth).

By depressing socio-economic development, inequality may consequently—indirectly—foster terrorist activity. This is because socio-economic grievances (due to, e.g., poor public health or slow economic growth) may give rise to terrorism. When socio-economic conditions are poor, violence (to counter such grievances) may be more attractive relative to non-violence; in other words, under such circumstances the opportunity costs of violence are particularly low (Freytag et al., 2011). Indeed, some empirical studies suggest that terrorism is more likely when socioeconomic conditions are unfavorable (e.g., Caruso and Schneider, 2011; Freytag et al., 2011; Brockhoff et al., 2015).

However, the evidence on the determinants of terrorism does not conclusively show that terrorism is rooted in poor socio-economic conditions. In their extensive analysis of the potential determinants of terrorism, Gassebner and Luechinger (2011: 255) come to the conclusion that "[...] the preponderance of evidence suggests that the level of economic development is of minor importance [for terrorism] at best.” In their review article, Krieger and Meierrieks (2011: 19) conclude that economic factors matter less to the genesis of terrorism than institutional variables, arguing that "[...] little evidence indicates that poor economic conditions alone cause terrorism. [...] [T]he institutional order seems to trump the economic one.” Indeed, a number of studies suggest that sound institutions also deter terrorism (e.g., Basuchoudhary and Shughart, 2010; Choi, 2010; Gassebner and Luechinger, 2011). For instance, Choi (2010) finds that terrorism is more likely in countries that are characterized by a deficient rule of law. 
Importantly, inequality may also affect a country's institutional conditions, leading to poorer politico-institutional outcomes. For instance, the rich may use their wealth, be it legally through political contributions or illegally through corruption, to buy favorable legislation and court decisions, consequently subverting the rule of law and the security of property rights (Glaeser et al., 2003). Evidence provided by, e.g., Jong-sun and Khagram (2005), Easterly (2007) and Loyaza et al. (2012) indeed suggests that inequality is associated with more corruption, less economic freedom and market-friendliness, reduced government effectiveness and a weaker rule of law. This opens up an additional indirect pathway from inequality to terrorism: Inequality leads to the erosion of institutions, which in turn creates grievances potentially fueling terrorism.

Main Hypothesis. In sum, theory suggests that inequality may — directly—lead to more terrorist activity by fueling frustration in accordance with relative deprivation theory, where terrorism serves as a means to voice discontent over and eventually change the economic-distributional status quo. Furthermore, inequality may—indirectly—fuel terrorism by contributing to poorer socio-economic outcomes (e.g., health, education) and impairing institutions (e.g., corruption control, the rule of law), which in turn may incite terrorism. This leads to the following hypothesis:

Hypothesis: A higher level of income inequality is associated with more terrorist activity.

Empirical Evidence. As hinted at in the introduction, the empirical evidence on the relationship between income inequality and terrorism is sparse. As part of their review of 43 empirical studies on the determinants of terrorism, Gassebner and Luechinger (2011: 241) find that only eight of them consider the role of income inequality in terrorism. What is more, in several of the reviewed studies it is only controlled for income inequality as a robustness check. For instance, Abadie (2006) considers the effect of income inequality on terrorism in only one of eleven presented model specifications. Closest to our study is Piazza (2006) who provides a broad analysis of the impact of economic deprivation, measured in absolute (poverty, malnutrition) as well as relative (income inequality) terms, and socio-economic grievances (e.g., in terms of unemployment and inflation) on terrorism for a sample of 96 countries from 1986 to 2002. Piazza (2006) finds no support for the hypothesis that a country's income distribution is related to terrorism. Other studies that control for the effect of inequality on 
terrorism similarly provide little evidence that income inequality consistently matters (e.g., Li, 2005; Abadie, 2006; Kurrild-Klitgaard et al., 2006; Kis-Katos et al., 2014). ${ }^{2}$

The scarcity of evidence on the inequality-terrorism relationship additionally motivates our empirical analysis. As already stressed in the introduction, we want to add to the existing evidence by (i) using more recent and consistent data (especially with respect to income inequality), allowing us to consider a larger sample, (ii) examining the role of endogeneity, (iii) studying in more detail the transmission channels from income inequality to terrorism and (iv) analyzing how the reduction of income inequality through taxation and other policies (i.e., redistribution) is associated with terrorism.

\section{Data}

To test our main hypothesis on the relationship between inequality and terrorism, we collect data for 114 countries for the 1985-2012 period. Due to gaps in the data and to minimize the influence of measurement error and of longer-term cycles (e.g., business or political cycles), we average each variable in our dataset to create a maximum of seven non-overlapping 4-year averages for each country. The summary statistics are reported in Table 1. A country list is provided in the appendix.

\section{- Table 1 here-}

\subsection{Dependent Variables}

Our main dependent variable to indicate terrorist activity is the number of terrorist incidents per 4-year-period-country observation. This variable refers to all kinds of terrorist attacks such as assassinations, kidnappings, bombings and armed assaults. The attacks may be carried out by domestic, transnational or unknown actors. The data on the number of terrorist attacks is drawn from the Global Terrorism Database (GTD), first introduced in LaFree and Dugan (2007). ${ }^{3}$ The GTD defines terrorism as the threatened or actual use of illegal force and violence

\footnotetext{
2 This notion is also mirrored by the evidence on the relationship between inequality and civil war. For instance, Dixon (2009: 716) reviews 46 quantitative studies on the causes of civil war and comes to the conclusion that there is "relative paucity of evidence for the widespread assumption that 'vertical' economic inequality (as measured by Gini coefficients) produces civil war”.

${ }^{3}$ The most recent GTD data is available at http://tinyurl.com/m4bfw6.
} 
by non-state actors to attain a political, economic, religious or social goal through fear, coercion or intimidation.

As part of our robustness analysis, we use another variable also drawn from the GTD, the number of terrorism victims per 4-year-period-country observation. Here, victims refers to individuals injured or killed in a terrorist incident.

\subsection{Inequality Data}

In our study we measure income inequality by the Gini coefficient. The Gini coefficient measures, as an indicator of "vertical" income inequality, the extent to which the income distribution between individuals within an economy deviates from a perfectly equal distribution. It ranges from 0 (perfect equality) to 100 (perfect inequality). As shown by Yitzhaki (1979, 1982), the Gini coefficient can be interpreted as a quantification of relative deprivation theory. That is, higher values of the Gini coefficient coincide with higher relative deprivation in a society and thus lower social satisfaction (Yitzhaki, 1979, 1982). What is more, using the Gini coefficient may allow us to capture the indirect linkages between inequality and terrorism. For instance, higher income inequality also plausibly coincides with greater opportunities for the rich to shape institutions in their favor, consequently resulting in lower institutional quality and, consequently, more terrorism. Similarly, it is expected to coincide with greater economic vulnerability of the poor, which may limit their options to, e.g., invest in education and health, consequently leading to poorer socio-economic outcomes due to inequality that may subsequently incite terrorism. In sum, we believe the Gini coefficient to be a sound indicator to test our main hypothesis of direct and indirect effects of inequality on terrorism.

The data for the Gini coefficient come from the Standardized World Income Inequality Database (SWIID) (Solt, 2009). From the SWIID we extract the Gini coefficient of net income, i.e., we consider the level of inequality that persists after taxes and other forms of redistribution are taken into account. Net-income inequality (rather than income inequality produced by the market-place) is the kind of inequality actually felt by society and can thus considered to be a potential breeding ground for frustration and, ultimately, terrorism; the differences between netand market-income inequality the inequality-terrorism nexus are analyzed in Subsection 4.4.

We use the SWIID for three reasons. First, by means of computational imputation the SWIID has, in comparison to other inequality datasets (e.g., the Luxembourg Income Study), a greater 
coverage with respect to both time and space (Solt, 2009; Ferreira et al., 2015). ${ }^{4}$ Second, by means of computational procedures the SWIID also aims at improving the comparability of income inequality statistics between countries. This standardization of inequality data allows for more consistent cross-national research (Solt, 2009). Third, the SWIID provides data on inequality before and after taxation and other forms of redistribution. This allows us to explicitly consider the influence redistribution has on terrorism (Subsection 4.4).

\subsection{Control Variables}

We choose a set of control variables according to the literature reviews of Gassebner and Luechinger (2011) and Krieger and Meierrieks (2011).

First, we consider the impact of regime type (democracy) on terrorism. We use the Polity2 score from the Polity IV Project (Marshall et al., 2014). The variable ranges from -10 (strongly autocratic) to +10 (strongly democratic), depending on how a country's political system and institutions (e.g., with respect to the openness of political competition) are organized. Democratic institutions enable political participation, thus potentially making terrorist violence a less attractive option to achieve political goals ( $\mathrm{Li}, 2005$ ). However, it is also possible that the protection of civil liberties and political freedoms by democratic institutions may compromise counter-terrorism measures, e.g., by making the surveillance of potential terrorists more difficult, leading to more terrorism (Li, 2005). Given these two diametrically opposed lines of reasoning on the role of democracy in terrorism, we remain agnostic about the expected effect of the former on the latter.

Second, we control for regime stability. It is measured by the variable durable also drawn from the Polity IV Project. It measures the number of years since the most recent regime change (defined by at least a three-point change in the Polity2 score over a period of three years or

\footnotetext{
${ }^{4}$ Ferreira et al. (2015) provide a critical discussion of various cross-country datasets on income inequality. They argue that the SWIID's use of imputation methods to increase its coverage and comparability may negatively affect the SWIID's reliability especially when these methods are applied to data-poor regions (e.g., developing countries). As with the other inequality datasets discussed in Ferreira et al. (2015), there is thus a trade-off between data coverage and quality. Following, inter alia, Jong-sun and Khagram (2005), we try to minimize any measurement error in inequality by averaging the data over the observation period, creating a series of 4-year averages.
} 
less). We expect a negative relationship between regime stability and terrorism. That is, more instable regimes ought to be more likely to experience terrorism. For instance, domestic instability may create power vacuums that make it easier to carry out terrorism (e.g., as counterterrorism means are constrained), while also positively influencing the possibility of terrorist success (e.g., as an instable regime is more likely to be overwhelmed by terrorists).

Third, we control for population size. It is measured by a country's (logged) number of residents (except for refugees), with the data coming from the World Development Indicators (World Bank, 2014). Consistent with the very robust evidence from the existing literature on the determinants of terrorism (Gassebner and Luechinger, 2011; Krieger and Meierrieks, 2011), we expect population size to be a positive predictor of terrorism. For one, this may be due to higher policing costs associated with larger populations, which may complicate counter-terrorism efforts. For another, the positive association between population size and terrorism may be due to a scale effect, given that larger countries ought to have more terrorism targets, victims and potential terrorists.

Fourth, we consider the effect of economic development, measured by a country's (logged) per capita income at constant 2005 US\$. ${ }^{5}$ The data also come from the World Development Indicators. Poor economic conditions may create grievances that result in terrorism. For instance, Freytag et al. (2011) argue that lower levels of income coincide with lower opportunity costs of violence, making it more attractive to challenge the existing economic status quo by means of terrorism. Thus, we expect per capita income to be negatively related to terrorism.

Fifth, we control for the effect of external conflict on terrorism, measured by an indicator accounting for the risk to local governments due to foreign action (e.g., due to diplomatic pressures and sanctions, but also military cross-border conflicts and interstate war). The data are drawn from the International Country Risk Guide (PRS Group, 2014). As stressed by Conrad (2011) and Findley et al. (2012), conflicts between states may lead to terrorist activity. For instance, countries may actively or passively support terrorist activity against their foreign

\footnotetext{
${ }^{5}$ As part of our robustness analysis, we replace per capita income with two alternative measures of socio-economic development, child mortality and life expectancy (both variables also coming from the World Development Indicators). One may expect these latter variables to be less likely to be endogenous to terrorism. However, using these alternative indicators does not change our empirical findings (results available upon request).
} 
policy rivals so as to weaken these rivals and boost their own domestic and international position. Thus, we expect countries engaged in external conflict to experience more terrorist activity.

Finally, we control for government consumption, measured by the ratio of general government final consumption expenditures to a country's GDP, with the data being drawn from the World Development Indicators. This variable accounts for all government expenditures for purchases of goods and services, employee compensation and most expenditures on national defense and security. Kurrild-Klitgaard et al. (2006) discuss two (diametrically opposed) theoretical relationships between government size and terrorism. For one, more government activity may create large rents that terrorists want to capture, leading to more terrorist activity. For another, more government spending (e.g., on internal security) may make it easier to quell opposition or accommodate grievances, suggesting that government size and terrorism correlate negatively. Given these two lines of reasoning, we remain agnostic about the expected effect of government spending on terrorism.

As part of our robustness analysis, we amend our baseline model with additional variables. First, we include additional covariates indicating a country's level of ethnic tensions and religious tensions. The variables come from the International Country Risk Guide. Both types of tensions ought to lead to more terrorism by giving rise to additional ethno-religious grievances (e.g., due to discrimination). Indeed, previous research has shown that ethnic tensions are positively associated with terrorist activity (Basuchoudhary and Shughart, 2010). Second, we add a lagged dependent variable to our model. The inclusion of a lag of the dependent variable is expected to ameliorate any remaining serial correlation problems. ${ }^{6}$

\footnotetext{
${ }^{6}$ Further covariates we added to our baseline model are a country’s economic growth and inflation rates, its population density and population growth rates as well as measures of urbanization, globalization (e.g., external economic openness) and quality of bureaucracy. The estimates of our baseline model (especially with respect to the effect of inequality on terrorism) are robust to the inclusion of these additional controls. Our results also hold when we drop the advanced OECD countries (which tend to most strongly distribute wealth) and/or the Cold War era period (i.e., the data from 1985 to 1992) from our sample. All of these additional robustness checks are available upon request.
} 


\section{Empirical Results}

\subsection{Main Results}

In order to assess the influence of income inequality on terrorism, for our main empirical analysis we run a series of negative binomial regressions. We choose this econometric method due to the count-data nature of our dependent variables (the number of terrorist attacks and terrorism victims, respectively) which exhibit over-dispersion (i.e., variances larger than their respective means). ${ }^{7}$ When estimating the count-data models, we include-in addition to the controls discussed above-a set of regional and period dummies to control for heterogeneity, autocorrelation and trending effects. To further account for characteristics that are inherent in panel data, we use country-clustered standard errors that are robust to heteroskedasticity and autocorrelation.

The negative binomial regression results are reported in Table 2. Considering our main variable of interest, we find that higher levels of income inequality are associated with more terrorist activity. This effect is robust to different model specifications and the use of a different dependent variable (the number of terrorism victims). That is, the negative binomial regression results are is in line with our main hypothesis. The terrorism-inducing effect of inequality may be due to frustration generated by relative deprivation, but potentially also poorer social conditions rooted in inequality; we shall analyze the related potential transmission channels in more detail below (Subsection 4.3).

\section{- Table 2 here-}

After having established that inequality is robustly associated with terrorism, we now briefly consider the controls. First, we find that democracy is positively related to terrorism. This may indicate that democracies are more vulnerable to terrorism due to their respect for civil liberties which hampers counter-terrorism measures. However, the positive association between democratic institutions and terrorism may also be due to a reporting bias, meaning that in democracies (due to them having a free press) terrorism is simply more likely to be reported compared to more autocratic regimes ( $\mathrm{Li}, 2005)$. Thus, we do not want to overemphasize our finding regarding the democracy-terrorism relationship. Second, we find weak evidence that

\footnotetext{
${ }^{7}$ We also estimate our baseline model using other econometric approaches (e.g., a zero-inflated negative binomial regression approach). As shown in the appendix, our main findings remain robust to the use of alternative estimation approaches.
} 
regime durability deters terrorism. This may indicate that instable regimes invite terrorism by offering power vacuums terrorist organizations may try to fill. Third, population size is a positive predictor of terrorism. For one, this may be due to policing costs that increase with population size and thereby reduce counter-terrorism efficiency. For another, countries that are more populous may see more terrorism because larger countries simply provide a larger pool of potential terrorists and terrorism targets. Fourth, external conflict is conducive to terrorism. This speaks to a number of more recent studies that find that international political factors are important determinants of terrorism (Conrad, 2011; Findley et al., 2012). Fifth, we also findas part of our robustness analysis - that ethnic and religious tensions are associated with more terrorism. This suggests that ethnic and religious grievances (e.g., due to discrimination) also matter to terrorism, as previously suggested in Basuchoudhary and Shughart (2010). Finally, we find no evidence that government consumption and per capita income are associated with terrorism. The latter finding speaks to the empirical mainstream that economic developmentmeasured in terms of per capita income-shares no robust relationship with terrorism (Gassebner and Luechinger, 2011; Krieger and Meierrieks, 2011).

Finally, we want to consider the substantive effects of inequality on terrorism. Potentially, statistically significant results do not translate into economically meaningful (i.e., sizeable) effects. To study the substantiveness of the effect of inequality on terrorism, we transform the regression coefficients associated with the baseline model (specification (1) in Table 2) into incidence-rate ratios (IRR) (reported as specification (6) in Table 2). The IRR associated with income inequality is $I R R=1.072$. This means that a one-unit increase in income inequality (i.e., a one-percent increase in the Gini coefficient) leads, ceteris paribus, to a 7.2 percent increase in the number of terrorist attacks, pointing to a moderately substantive effect of inequality on terrorism. ${ }^{8}$

Another way to examine the quantitative effect of inequality on terrorism is to study (graphically) the predictive marginal effects, as presented in Figure 1. Here, we hold all covariates from specification (1) at their respective means (regional and time dummies are held at zero) and only vary the level of inequality. Again, we are able to show that the effect of

\footnotetext{
${ }^{8}$ Upward (downward) movements of the Gini coefficient by several percentages points between two 4-year periods are fairly common in our sample. In the light of our findings, such inequality dynamics may very well result in rather strong increases (decreases) in terrorism.
} 
inequality on terrorism is economically substantive. For instance, while our model predicts approximately 25 terrorist incidents over a 4-year period for a Gini coefficient of 30 (approximately one standard deviation below the sample mean for inequality), at a Gini coefficient of 38 (the sample mean) we predict 35 incidents, while at a Gini coefficient of 50 (approximately one standard deviation above the mean) our model predicts roughly 60 terrorist incidents.

\section{-Figure 1 here-}

\subsection{Endogeneity}

In this subsection we want to examine whether our estimation results are affected by endogeneity. In particular, endogeneity in the inequality-terrorism nexus may be due to simultaneity. That is, income inequality may not only affect terrorism, but terrorism may also have distributional consequences.

First, terrorism may affect public spending, with spending on the military and security usually being prioritized in times of a terrorist threat over public expenditures for education, health and other public services (Gupta et al., 2004). Such effects may feed through to the economy's income distribution, e.g., as social welfare programs designed to reduce inequality are cut in favor of security spending. Second, terrorism may reduce a country's tax base (e.g., by reducing economic activity through increased insecurity) and decrease the efficiency of its tax administration (Gupta et al., 2004). This ought to constrain the amount of resources available to the government for public spending on (inequality-reducing) welfare programs. Third, terrorism may benefit some industrial sectors, while damaging others. For instance, Berrebi and Klor (2010) show that terrorism has positively contributed to the economic success of defencerelated industries in Israel (e.g., by creating demand for security products), but has hurt nondefence-related industries. Again, such effects may have distributional consequences. Wages in defence-related industries are likely to increase, while wages in other industries negatively affected by terrorism (e.g., tourism) may suffer. ${ }^{9}$

\footnotetext{
${ }^{9}$ Considering that wage levels in some services industries affected by terrorism (such as tourism) tend to be low in the first place, while wage levels in defence-related industries should be higher, the distributional consequences of terrorism may be even more pronounced.
} 
To consider endogeneity in the inequality-terrorism nexus, we use the instrumental-variable (IV) GMM-Poisson pseudo-maximum likelihood (PPML) estimators described in, e.g., Windmeijer and Santos Silva (1997). We compare the IV-estimates to estimates using the ordinary PPML estimator described in Gourieroux et al. (1984) to assess the magnitude of any endogeneity bias. Importantly, neither the ordinary PPML nor its IV-GMM variant rely, as Poisson pseudo-maximum likelihood estimators (in contrast to the more well-known Poisson maximum-likelihood estimator), on the assumption of equi-dispersion, i.e., on the data following a Poisson distribution; both the PPML and IV GMM-PPML estimator are fully robust to over-dispersion. To account for endogeneity, the IV GMM-PPML estimator uses an instrument for inequality to specify moment conditions that hold in the population, where the instrument is assumed to be correlated with the endogenous regressor (i.e., the Gini coefficient) but independent of the error term. The GMM estimates make the sample versions of these population-moment conditions to approximate their true values (Windmeijer and Santos Silva, 1997).

In our study, we instrument inequality by the relative size of mature-aged cohorts. It is operationalized as the size of the population between the ages of 40 and 59 to a country's (total working-age) population between the ages of 15 and 69. The population data are drawn from United Nations Population Division (2015).

This instrument was proposed by Higgins and Williamson (2002) and consequently used by, inter alia, Jong-sun and Khagram (2005) and Leigh (2006). Higgins and Williamson (2002) argue that "fat cohorts" tend to get lower economic rewards. When the mature-aged cohorts are relatively large (i.e., "fat”), this ought to lead to a more equal distribution of income due to more labor market competition. In the words of Higgins and Williamson (2002: 269):

"When those fat cohorts lie in the middle of the age-earnings curve, where life-cycle income is highest, [a] labor market glut lowers their income, thus tending to flatten the age earnings curve. Earnings inequality is moderated.”

Following this line of reasoning, we expect a negative association between relative mature-aged cohort size and inequality. Indeed, their correlation coefficient is $r=-0.64(p<0.01)$. A regression of inequality (GINI) on relative mature-aged cohort size (MACS) and a set of period dummies for each 4-year period $t$ (coefficients for period dummies not reported) yields the following regression equation (standard errors clustered over countries $i)\left(R^{2}=0.45\right)$ : 


$$
\operatorname{GINI}_{i, t}=65.003-102.612 * \text { MACS }_{i, t}
$$

From this regression equation we can see that mature-aged cohort size is indeed a strong negative predictor of income inequality. At the same time, we expect terrorism to be affected by relative mature-cohort size only through the latter's effect on income inequality. Indeed, running a negative binomial regression (country-clustered standard errors in parentheses) where the number of terrorist incidents (NINC) is explained by MACS and a set of time dummies (results for the latter not reported) yields the following regression equation (Pseudo- $R^{2}=0.01$ ), showing no significant effect if relative mature-aged cohort size on terrorism:

$$
N I N C_{i, t}=5.859-4.004 * M A C S_{i, t}
$$

This finding notwithstanding, one may argue that the inverse of a society with a relatively large mature working-age population, i.e., a particularly young society, may produce more terrorism. However, even though individual (active) terrorists tend to be younger, there is no convincing macro-level evidence that countries with younger populations actually produce more terrorism. For instance, Gassebner and Luechinger (2011: 254) come to the conclusion that "citizens from countries with a large share of young people are less likely to be victimized and, importantly, not more likely to commit attacks. Especially the latter result contradicts the literature on 'youth bulge'.” Thus, we believe that our identification strategy of instrumenting inequality with "fat cohorts” is appropriate.

The Poisson pseudo-maximum likelihood estimates are reported in Table 3. First, the results show that inequality remains a robust positive predictor of terrorism, regardless of whether we instrument it or not. ${ }^{10}$ That is, our results-also with respect to the controls-are robust to another alternative estimation technique. Our main hypothesis is again supported by the data. Second, the bias due to endogeneity does not appear to be large. If any, we tend to underestimate the effect of inequality on terrorism when endogeneity is not considered. Considering our

\footnotetext{
${ }^{10}$ The IV GMM-PPML model in specification (4) is estimated without regional dummies as they are not jointly significant $\left(\chi^{2}(5)=1.90, p=0.86\right)$. The regional dummies are, however, jointly significant for the ordinary PPML model $\left(\chi^{2}(5)=10.87, p=0.05\right)$ and are thus included in specification (3) to avoid omitted variable bias. The period dummies are jointly significant for both the IV GMM-PPML and ordinary PPML model.
} 
previously reported findings (Subsection 4.1), this suggests that our estimated effects of inequality on terrorism are rather conservative.

\section{- Table 3 here-}

\subsection{Transmission Channels}

When discussing the literature on the inequality-terrorism nexus, we argued that inequality may promote terrorism (i) directly due to the frustration-aggression mechanism described in relative deprivation theory and (ii) indirectly due to the unfavorable effects of inequality on various institutional or socio-economic factors which in turn may incite terrorism. So far, our empirical analysis has provided evidence that inequality is indeed conducive to terrorism. In this subsection we study which transmission channels explain this association.

Indirect Linkages. As stressed above, we argue that a number of unfavourable socio-economic and institutional conditions that determine terrorism are in turn-partly-rooted in income inequality and are thus mediators accounting for the positive association between inequality and terrorism. For instance, according to Jong-sun and Khagram (2005) income inequality may undermine the rule of law as the rich are more likely to use bribery to buy favourable legislation and court decisions; a weaker rule of law consequently makes a country more vulnerable to terrorism, as shown by Choi (2010).

To examine whether various potential socio-economic and institutional mediators are indeed determined by income inequality, we run a series of OLS and IV-OLS regressions of these mediators on inequality. In the IV-OLS regressions inequality is again instrumented by the relative size of mature cohorts. The potential socio-economic mediators are education (gross tertiary school enrollment), health (life expectancy) and domestic investment (measured by per capita fixed capital formation). All data are drawn from the World Development Indicators. The potential institutional mediators we consider are the rule of law, economic freedom (property rights protection) and corruption. These latter variables come from the International Country Risk Guide. The summary statistics for all potential mediators can be found in Table 1. 
The OLS and IV-OLS estimates are reported in Table $4 .{ }^{11}$ We find only limited support that inequality contributes to poor socio-economic outcomes. While inequality reduces tertiary education, it does not consistently lead to a lower life expectancy or less domestic investment. By contrast, there is strong evidence that income inequality leads to an erosion of institutional quality. From both the OLS and IV-OLS regressions we find that income inequality leads to a poorer rule of law and less economic freedom, while being positively associated with corruption. In sum, these findings suggest that any indirect effect of inequality on terrorism may materialize primarily through the deterioration of institutional conditions.

\section{- Table 4 here-}

Direct Linkages. Relative deprivation theory suggests that inequality and terrorism are directly related. Discontent over to the distribution of income is expressed in the form of terrorist violence; terrorism is a means to vent frustration and change the distribution of income in one's favor.

To study the relevance of this link, also in comparison to any indirect linkages from inequality to terrorism, we follow the 4-step procedure outlined in, e.g., Wu and Zambo (2008: 373-374). In the first step, we establish that the independent variable (inequality) is associated with the dependent variable (terrorism); this was already documented in Tables 2 and 3. For the second step, we show that the independent variable (inequality) is associated with the mediators; this was already shown in Table 4. In the third step, we regress terrorism on both inequality and the mediator variables. The corresponding findings are reported in Table 5. Finally, step 4 involves comparing the results obtained from a regression that does not consider the mediators with the results from a regression where the mediators are also accounted for; if the mediators completely mediate the inequality-terrorism relationship, the direct effect of inequality on terrorism should turn to zero once we also control for the mediators (Wu and Zambo, 2008).

\section{- Table 5 here-}

\footnotetext{
${ }^{11}$ For the IV-OLS estimates we can always soundly reject the null hypothesis of a weak instrument, given that the first-stage F-test statistics are always substantially larger than 10 . However, in some cases (e.g., for the rule of law IV-regression) an IV-approach would not have been necessary, given that for these cases we cannot reject the null hypothesis of the exogeneity of inequality (robust score test results).
} 
Table 5 shows that when we also consider the mediators, the regression coefficient associated with income inequality becomes—as expected—smaller. ${ }^{12}$ A number of the mediators (tertiary school enrollment, domestic investment, rule of law and corruption) share a statistical significant relationship with terrorism, where the direction of these effects is always as expected. For instance, in line with Choi (2010) we find that a stronger rule of law is associated with less terrorism. Still, even after controlling for all mediators, income inequality exerts a statistically significant and positive effect on terrorism. In line with Wu and Zambo (2008), this suggests that there is a direct effect of inequality on terrorism in addition to any indirect effect originating from the ill effects of inequality on economic or institutional conditions. What is more, comparing the regression coefficients for inequality in the two specifications reported in Table 5 by means of a seemingly-unrelated estimation (SUE) approach, we cannot reject the null hypothesis that the two coefficients are not different from each other $\left(\chi^{2}(1)=2.11, p=0.15\right)$. This suggests that the indirect effects of inequality on terrorism we consider in our analysis matter far less to the emergence of terrorism than the direct effects of inequality on terrorism that are consistent with relative deprivation theory.

\subsection{The Role of Redistribution}

In the light of our findings, how can the inflammatory effects of income inequality on terrorism be alleviated? Redistribution appears to be a powerful policy tool. The reduction of income inequality through taxation and welfare policies implemented by national governments ought to reduce grievances and frustration due to inequality that may otherwise result in terrorism. Finding evidence for a beneficial effect of redistribution on terrorism would be supportive of a small body of research (Burgoon, 2006; Krieger and Meierrieks, 2010) emphasizing the beneficial role of functioning social welfare systems in reducing terrorism.

To study the role of redistribution in the inequality-terrorism nexus, we extract another income inequality variable from the Standardized World Income Inequality Database, the Gini coefficient based on gross income, i.e., before taxes and other forms of redistribution are

\footnotetext{
${ }^{12}$ Note that the findings reported in specification (1) of Table 5 do not fully correspond to those reported in specification (1) of Table 2 because the number of observations is now somewhat smaller (592 vs. 681 observations). We reduce the number of observations in specification (1) of Table 5 to make these findings directly comparable to those in specification (2) of Table 5 , so as to be able to differentiate between the direct and indirect effects of inequality on terrorism.
} 
considered (market-level income inequality). Dividing market-level income inequality by netincome inequality (the indicator we used for all previous empirical efforts) yields another variable called redistribution, where a higher value of this latter variable corresponds to stronger redistribution.

In Table 6 we present negative binomial regression results successively employing net inequality, gross (market-level) inequality and the redistribution indicator as explanatory variables. The results indicate that higher levels of income inequality both before and after redistribution are associated with more terrorist incidents. Comparing the regression coefficients for both inequality measures by means of SUE analysis, we cannot reject the null hypothesis that the two coefficients are not different from each other $\left(\chi^{2}(1)=1.74, p=0.19\right)$. That is, regardless of how inequality is operationalized, we again find evidence in favor of our main hypothesis.

However, the level of inequality is usually markedly lower after redistribution. The mean Gini coefficient for our sample before redistribution is 45.39 , while it is only 38.10 after redistribution is considered; this difference in means is also statistically significant $(t=16.15$, $p<0.01$ ). Thus, on average countries can expect to see less terrorism after redistribution. This is also supported by the findings for our redistribution variable. Here, a higher level of redistribution is associated with less terrorism at conventional levels of statistical significance.

\section{- Table 6 here-}

Finally, we want to consider the substantive effect of redistribution on terrorism. To do so, we transform the regression coefficient associated with the redistribution variable in Table 6 into an IRR. The IRR associated with the redistribution variable is $I R R=0.29$. This means that a one-unit increase in the redistribution variable is, ceteris paribus, associated with a 71 percent decrease in terrorism over a 4-year period. This effect is clearly economically substantive. The predictive marginal effects of redistribution on terrorism are plotted in Figure 2, where the remaining covariates are held at their mean (regional and time dummies are held at zero) and only the values of the redistribution variable are varied. This analysis also shows that the effect of redistribution on terrorism is both statistically and economically meaningful. While our model predicts approximately 56 terrorist incidents over a 4-year period when the redistribution variable is equal to unity (meaning that inequality is identical before and after redistribution), we only predict approximately 9 terrorist incidents over the same time period when the 
redistribution variable is equal to two (meaning that inequality is cut in half due to redistribution). ${ }^{13}$ In sum, these findings suggests that countries may be able to substantially reduce their terrorism risk through redistributive government actions (i.e., through tax and social welfare policies).

\section{—Figure 2 here-}

\section{Conclusion}

In this contribution we study the effect of income inequality on terrorism for a sample of 114 countries between 1985 and 2012. We provide robust evidence that higher levels of income inequality are associated with more terrorism. This effect is also economically substantive. We argue that this effect is primarily a direct consequence of frustration over the distribution of income within a society, resulting in aggression (terrorism) to voice dissent and achieve a redistribution of wealth through terrorist action; this argument is consistent with relative deprivation theory. Furthermore, inequality may also indirectly contribute to terrorism by impairing social conditions which in turn incite terrorism. We provide some evidence that such indirect linkages also matter, where an erosion of institutions (e.g., the rule of law) due to inequality is found to matter more strongly than a deterioration of socio-economic conditions.

The major implication of our analysis is that policymakers can reduce the risk of terrorism by keeping inequality in check. As evidenced by our study, redistributional efforts (which ameliorate income inequality created on the market-place) can be quite effective in reducing inequality and, consequently, terrorist activity. Policymakers are, however, well advised to also consider the trade-off between redistribution and economic activity. Strong redistribution tends to coincide with high taxation and potentially excessive public spending, which may be harmful to economic growth by, e.g., introducing inefficiencies, crowding out private economic activity and unfavorably affecting saving and investment decisions (Scully, 2002). Consequently, a balanced policy approach that accounts for the potentially important roles of inequality and

\footnotetext{
${ }^{13}$ For instance, in our sample Sweden was able to halve income inequality, moving from an average pre-redistribution Gini coefficient of 45 to an average post-redistribution Gini coefficient of approximately 22. The country experienced 55 terrorist incidents between 1985 and 2012. A country were redistribution was almost absent is Colombia. Its average marketlevel Gini coefficient of 52 was only reduced to an average net Gini coefficient of 50. Between 1985 and 2012 the country saw over 5,700 terrorist incidents.
} 
redistribution in influencing and incentivizing both collective action (e.g., terrorism) and economic activity seems to be most promising.

\section{References}

Abadie, A. (2006). Poverty, political freedom, and the roots of terrorism. American Economic Review 96, 50-56.

Abadie, A., Gardeazabal, J. (2008). Terrorism and the world economy. European Economic Review 52, 1-27.

Alesina, A., Perotti, R. (1996). Income distribution, political instability, and investment. European Economic Review 40, 1203-1228.

Basuchoudhary, A., Shughart, W.F. (2010). On ethnic conflict and the origins of transnational terrorism. Defence and Peace Economics 21, 65-87.

Berrebi, C., Klor, E.F. (2010). The impact of terrorism on the defence industry. Economica 77, 518-543.

Brockhoff, S., Krieger, T., Meierrieks, D. (2015). Great expectations and hard times: The (nontrivial) impact of education on domestic terrorism. Journal of Conflict Resolution 59(7), 1186-1215.

Burgoon, B. (2006). On welfare and terror: Social welfare policies and political-economic roots of terrorism. Journal of Conflict Resolution 50, 176-203.

Caruso, R., Schneider, F. (2011). The socio-economic determinants of terrorism and political violence in Western Europe (1994-2007). European Journal of Political Economy 27, 3749.

Choi, S.-W. (2010). Fighting terrorism through the rule of law? Journal of Conflict Resolution 54, 940-966.

Conrad, J. (2011). Interstate rivalry and terrorism: An unprobed link. Journal of Conflict Resolution 55, 529-555.

Crain, N.V., Crain, W.M. (2006). Terrorized economies. Public Choice 128, 317-349.

Dixon, J. (2009). What causes civil wars? Integrating quantitative research findings. International Studies Review 11, 707-735.

Easterly, W. (2007). Inequality does cause underdevelopment: Insights from a new instrument. Journal of Development Economics 84, 755-776.

Ferreira, F.H.G, Lustig, N., Teles, D. (2015). Appraising cross-national income inequality databases: An introduction. Journal of Economic Inequality 13, 497-526. 
Findley, M.G., Piazza, J.A., Young, J.K. (2012). Games rivals play: Terrorism in international rivalries. Journal of Politics 74, 235-248.

Freytag, A., Krüger, J.J., Meierrieks, D., Schneider, F. (2011). The origins of terrorism: Crosscountry estimates of socio-economic determinants of terrorism. European Journal of Political Economy 27, 5-16.

Gassebner, M., Luechinger, S. (2011). Lock, stock, and barrel: A comprehensive assessment of the determinants of terror. Public Choice 149, 235-261.

Glaeser, E, Scheinkman, J., Shleifer, A. (2003). The injustice of inequality. Journal of Monetary Economics 50, 199-222.

Gourieroux, C., Monfort, A., Trognon, A. (1984). Pseudo maximum likelihood methods: Applications to Poisson models. Econometrica 52, 701-720.

Gupta, S., Clements, B., Bhattacharya, R., Chakravarti, S. (2004). Fiscal consequences of armed conflict and terrorism in low- and middle-income countries. European Journal of Political Economy 20, 403-421.

Gurr, T.R. (1970). Why Men Rebel. Princeton University Press: Princeton, NJ.

Higgins, M., Williamson, J.G. (2002). Explaining inequality the world round: Cohort size, Kuznets curves, and openness. Southeast Asian Studies 40, 268-302.

Jong-sun, Y., Khagram, S. (2005). A comparative study of inequality and corruption. American Sociological Review 70, 136-157.

Kis-Katos, K., Liebert, H. Schulze, G.G. (2014). On the heterogeneity of terror. European Economic Review 68, 116-136.

Krieger. T., Meierrieks, D. (2010). Terrorism in the worlds of welfare capitalism. Journal of Conflict Resolution 54, 902-939.

Krieger, T., Meierrieks, D. (2011). What causes terrorism? Public Choice 147, 3-27.

Kurrild-Klitgaard, P., Justesen, M.K., Klemmensen, R. (2006). The political economy of freedom, democracy and transnational terrorism. Public Choice 128, 289-315.

LaFree, G., Dugan, L. (2007). Introducing the Global Terrorism Database. Terrorism and Political Violence 19, 181-204.

Leigh, A. (2006). Does equality lead to fraternity? Economics Letters 93, 121-125.

Li, Q. (2005). Does democracy promote or reduce transnational terrorist incidents? Journal of Conflict Resolution 49, 278-297.

Loayza, N., Rigolini, J., Llorente, G. (2012). Do middle classes bring about institutional reforms? Economics Letters 116, 440-444. 
MacCulloch, R. (2005). Income inequality and the taste for revolution. Journal of Law and Economics 48, 93-123.

Marshall, M.G, Gurr, T.G., Jaggers, K. (2013). Polity IV Project: Political Regime Characteristics and Transitions, 1800-2013. Center for Systemic Peace: Vienna, VA.

Marx, K. (1848). Wage Labour and Capital. Available at http://tinyurl.com/md4v9vs.

Melnick, R, Eldor, R. (2010). Small investment and large returns: Terrorism, media and the economy. European Economic Review 54, 963-973.

Neckerman, K.M., Torche, F. (2007). Inequality: Causes and consequences. Annual Review of Sociology 33, 335-357.

Nitsch, V., Schumacher, D. (2004). Terrorism and international trade: An empirical investigation. European Journal of Political Economy 20, 423-433.

Piazza, J.A. (2006). Rooted in poverty? Terrorism, poor economic development, and social cleavages. Terrorism and Political Violence 18, 159-177.

PRS Group (2014). International Country Risk Guide. The PRS Group, Inc.: Syracuse, NY.

Sandler, T., Enders, W. (2008). Economic consequences of terrorism in developed and developing countries: An overview. In: Keefer, P., Loayza, N. (Eds), Terrorism, Economic Development, and Political Openness. Cambridge University Press: New York, NY, pp. 1747.

Scully, G.W. (2002). Economic freedom, government policy and the trade-off between equity and economic growth. Public Choice 113, 77-96.

Smith, A. (1776). An Inquiry into the Nature and Causes of the Wealth of Nations. London.

Solt, F. (2009). Standardizing the World Income Inequality Database. Social Science Quarterly 90, 231-242.

Thorbecke, E., Charumilind, C. (2002). Economic inequality and its socioeconomic impact. World Development 30, 1477-1495.

United Nations Population Division (2015). 2015 Revision of World Population Prospects. The United Nations: New York, NY.

Wilkinson, R.G., Pickett, K.E. (2007). The problems of relative deprivation: Why some societies do better than others. Social Science \& Medicine 65, 1965-1978.

Windmeijer, F.A.G., Santos Silva, J.M.C. (1997). Endogeneity in count data models: An application to demand for health care. Journal of Applied Econometrics 12, 281-294.

World Bank (2014). World Development Indicators. The World Bank: Washington, DC.

Wu, A.D., Zumbo, B.D. (2008). Understanding and using mediators and moderators. Social Indicators Research 87, 367-392. 
Yitzhaki, S. (1979). Relative deprivation and the Gini coefficient. Quarterly Journal of Economics 93, 321-324.

Yitzhaki, S. (1982). Relative deprivation and economic welfare. European Economic Review 17, 99-113. 


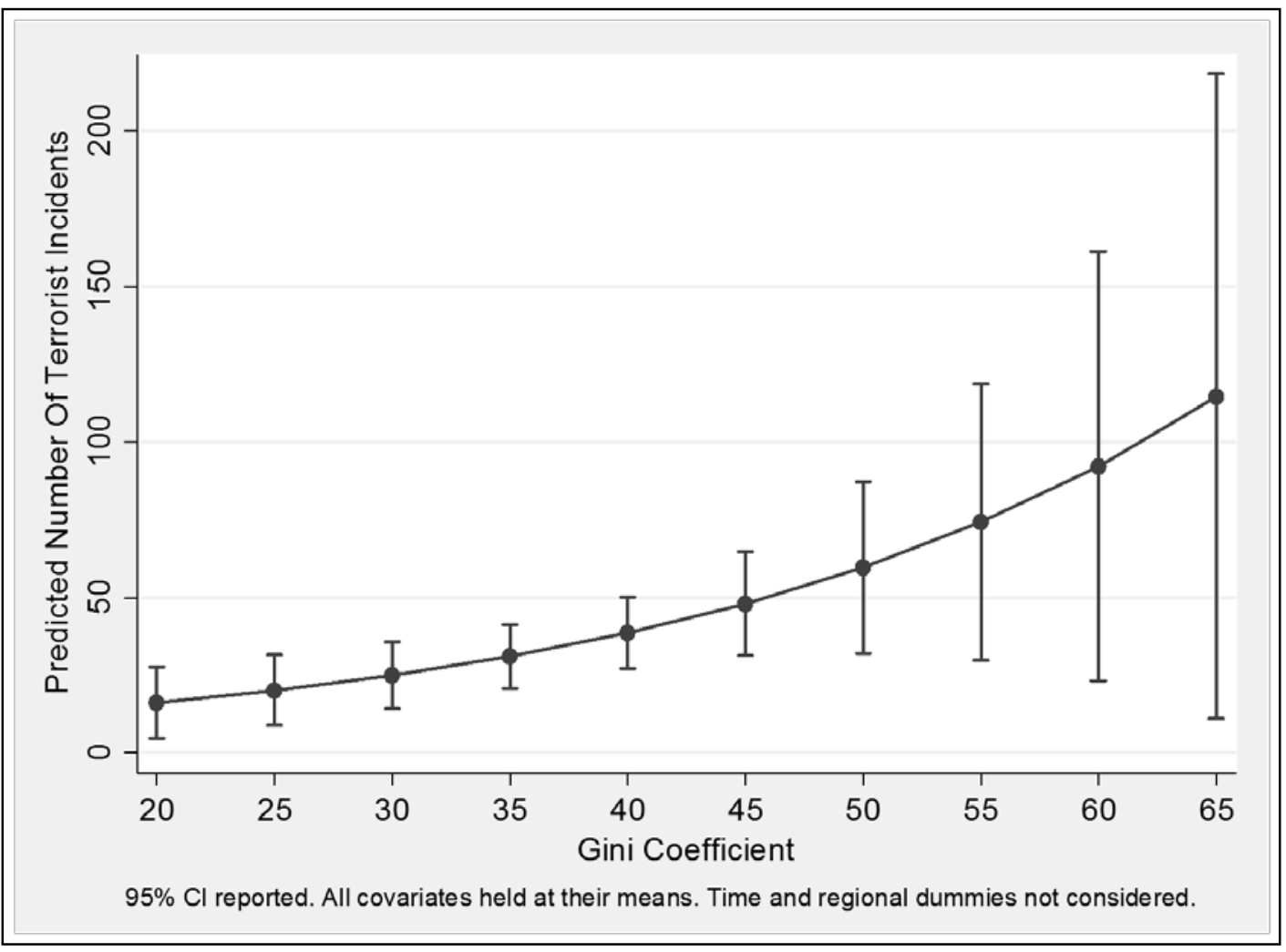

Figure 1: Predictive Margins for Various Levels of Income Inequality

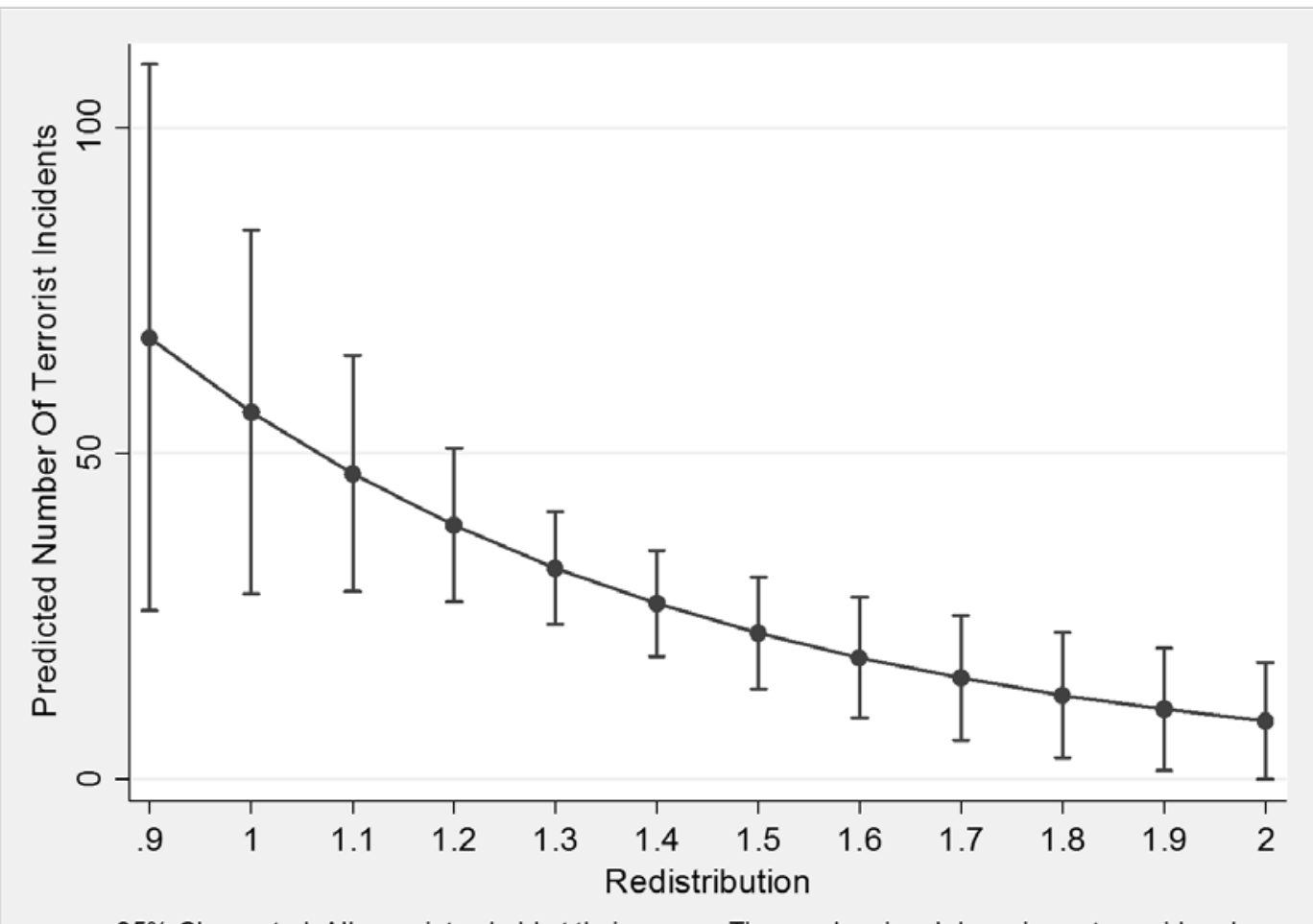

$95 \% \mathrm{Cl}$ reported. All covariates held at their means. Time and regional dummies not considered.

Figure 2: Predictive Margins for Various Levels of Redistribution 


\begin{tabular}{llllll}
\hline Variable & Observations & Mean & $\begin{array}{c}\text { Standard } \\
\text { Deviation }\end{array}$ & Minimum & Maximum \\
\hline Terrorist Incidents & 758 & 80.11 & 250.82 & 0 & 3674 \\
Terrorism Victims & 758 & 360.39 & 1207.94 & 0 & 18709 \\
Income Inequality & 693 & 38.10 & 9.37 & 19.87 & 66.63 \\
Democracy & 758 & 4.45 & 6.1 & -9 & 10 \\
Regime Durability & 758 & 27.47 & 32.7 & 0 & 201.5 \\
Population Size (logged) & 758 & 16.41 & 1.54 & 12.41 & 21.02 \\
Per Capita Income (logged) & 750 & 8.09 & 1.65 & 4.85 & 11.33 \\
External Conflict & 758 & 1.76 & 1.53 & 0 & 9.48 \\
Final Government Expenditure & 740 & 15.41 & 5.56 & 3.48 & 50 \\
Ethnic Tensions & 758 & 3.26 & 2.21 & 0 & 10 \\
Religious Tensions & 758 & 2.21 & 2.12 & 0 & 10 \\
\hline Mature Cohort Size & 758 & 0.29 & 0.06 & 0.17 & 0.44 \\
Income Inequality (Market) & 693 & 45.39 & 7.30 & 21.27 & 70.48 \\
Redistribution & 693 & 1.24 & 0.27 & 0.94 & 2.24 \\
\hline Tertiary Schooling & 660 & 28.94 & 24.42 & 0.16 & 113.98 \\
Life Expectancy & 758 & 67.55 & 10.54 & 35.9 & 82.86 \\
Domestic Investment & 731 & 21.63 & 5.87 & 1.07 & 50.25 \\
Rule of Law & 758 & 6.28 & 2.39 & 0.17 & 10 \\
Economic Freedom & 758 & 6.21 & 1.96 & 0.83 & 10 \\
Corruption & 758 & 4.75 & 2.18 & 0 & 10 \\
\hline
\end{tabular}

Table 1: Summary Statistics 


\begin{tabular}{|c|c|c|c|c|c|c|c|c|}
\hline & $(1)$ & (2) & (3) & (4) & (5) & (6) & (7) & (8) \\
\hline Income Inequality & $\begin{array}{l}0.069 \\
(0.017)^{* * *}\end{array}$ & $\begin{array}{l}0.060 \\
(0.017) * * *\end{array}$ & $\begin{array}{l}0.072 \\
(0.015) * * *\end{array}$ & $\begin{array}{l}0.032 \\
(0.014)^{* *}\end{array}$ & $\begin{array}{l}0.037 \\
(0.013) * * *\end{array}$ & $\begin{array}{l}1.072 \\
(0.018) * * *\end{array}$ & $\begin{array}{l}0.061 \\
(0.022) * * *\end{array}$ & $\begin{array}{l}0.056 \\
(0.014) * * *\end{array}$ \\
\hline Democracy & $\begin{array}{l}0.086 \\
(0.031)^{* * *}\end{array}$ & $\begin{array}{l}0.077 \\
(0.030)^{* *}\end{array}$ & $\begin{array}{l}0.099 \\
(0.024) * * *\end{array}$ & $\begin{array}{l}0.080 \\
(0.026) * * *\end{array}$ & $\begin{array}{l}0.073 \\
(0.021)^{* * *}\end{array}$ & $\begin{array}{l}1.090 \\
(0.033)^{* * *}\end{array}$ & $\begin{array}{l}0.046 \\
(0.035)\end{array}$ & $\begin{array}{l}0.004 \\
(0.027)\end{array}$ \\
\hline Regime Durability & $\begin{array}{l}-0.009 \\
(0.005)^{*}\end{array}$ & $\begin{array}{l}-0.008 \\
(0.004) *\end{array}$ & $\begin{array}{l}-0.006 \\
(0.005)\end{array}$ & $\begin{array}{l}-0.006 \\
(0.004)\end{array}$ & $\begin{array}{l}-0.005 \\
(0.003)^{*}\end{array}$ & $\begin{array}{l}0.991 \\
(0.005)^{*}\end{array}$ & $\begin{array}{l}-0.005 \\
(0.006)\end{array}$ & $\begin{array}{l}-0.009 \\
(0.004)^{* *}\end{array}$ \\
\hline Population Size & $\begin{array}{l}0.902 \\
(0.092)^{* * *}\end{array}$ & $\begin{array}{l}0.885 \\
(0.090)^{* * *}\end{array}$ & $\begin{array}{l}0.823 \\
(0.083)^{* * *}\end{array}$ & $\begin{array}{l}0.707 \\
(0.077)^{* * *}\end{array}$ & $\begin{array}{l}0.671 \\
(0.063)^{* * *}\end{array}$ & $\begin{array}{l}2.464 \\
(0.226)^{* * *}\end{array}$ & $\begin{array}{l}1.131 \\
(0.108)^{* * *}\end{array}$ & $\begin{array}{l}0.933 \\
(0.099) * * *\end{array}$ \\
\hline Per Capita Income & $\begin{array}{l}-0.100 \\
(0.225)\end{array}$ & $\begin{array}{l}-0.010 \\
(0.205)\end{array}$ & $\begin{array}{l}0.025 \\
(0.165)\end{array}$ & $\begin{array}{l}-0.180 \\
(0.169)\end{array}$ & $\begin{array}{l}0.005 \\
(0.130)\end{array}$ & $\begin{array}{l}0.905 \\
(0.204)\end{array}$ & $\begin{array}{l}-0.291 \\
(0.254)\end{array}$ & $\begin{array}{l}-0.051 \\
(0.131)\end{array}$ \\
\hline External Conflict & $\begin{array}{l}0.405 \\
(0.086)^{* * *}\end{array}$ & $\begin{array}{l}0.334 \\
(0.089) * * *\end{array}$ & $\begin{array}{l}0.362 \\
(0.061)^{* * *}\end{array}$ & $\begin{array}{l}0.392 \\
(0.081)^{* * *}\end{array}$ & $\begin{array}{l}0.315 \\
(0.068)^{* * *}\end{array}$ & $\begin{array}{l}1.500 \\
(0.129)^{* *}\end{array}$ & $\begin{array}{l}0.520 \\
(0.094)^{* * *}\end{array}$ & $\begin{array}{l}0.494 \\
(0.093) * * * *\end{array}$ \\
\hline Final Government Expenditure & $\begin{array}{l}0.002 \\
(0.020)\end{array}$ & $\begin{array}{l}-0.008 \\
(0.020)\end{array}$ & $\begin{array}{l}0.013 \\
(0.019)\end{array}$ & $\begin{array}{l}0.010 \\
(0.019)\end{array}$ & $\begin{array}{l}0.010 \\
(0.017)\end{array}$ & $\begin{array}{l}1.002 \\
(0.020)\end{array}$ & $\begin{array}{l}0.035 \\
(0.025)\end{array}$ & $\begin{array}{l}0.026 \\
(0.022)\end{array}$ \\
\hline Ethnic Tensions & & $\begin{array}{l}0.198 \\
(0.056) * * *\end{array}$ & & & $\begin{array}{l}0.120 \\
(0.045)^{* * *}\end{array}$ & & & $\begin{array}{l}0.153 \\
(0.058)^{* * *}\end{array}$ \\
\hline Religious Tensions & & & $\begin{array}{l}0.361 \\
(0.053) * * *\end{array}$ & & $\begin{array}{l}0.235 \\
(0.048) * * *\end{array}$ & & & $\begin{array}{l}0.314 \\
(0.067)^{* * *}\end{array}$ \\
\hline Lagged Dependent Variable & & & & $\begin{array}{l}0.004 \\
(0.001)^{* * *}\end{array}$ & $\begin{array}{l}0.004 \\
(0.001)^{* * *}\end{array}$ & & & $\begin{array}{l}0.001 \\
(0.000)^{* * *}\end{array}$ \\
\hline Dependent Variable & Attacks & Attacks & Attacks & Attacks & Attacks & Attacks & Victims & Victims \\
\hline Regional Dummies & Yes & Yes & Yes & Yes & Yes & Yes & Yes & Yes \\
\hline Time Dummies & Yes & Yes & Yes & Yes & Yes & Yes & Yes & Yes \\
\hline Pseudo $\mathrm{R}^{2}$ & 0.091 & 0.097 & 0.108 & 0.124 & 0.139 & 0.091 & 0.057 & 0.080 \\
\hline Number of Observations & 681 & 681 & 681 & 602 & 602 & 681 & 681 & 602 \\
\hline
\end{tabular}

Notes: Constant not reported. Attacks $=$ Number of terrorist attacks. Victims $=$ Number of terrorism victims. Specification (6) reports the IRR for specification (1). Robust country-clustered standard errors in parentheses. ${ }^{*} \mathrm{p}<0.1,{ }^{* *} \mathrm{p}<0.05,{ }^{* * *} \mathrm{p}<0.01$.

Table 2: Terrorism and Income Inequality 


\begin{tabular}{|c|c|c|c|c|}
\hline & $(1)$ & $(2)$ & (3) & (4) \\
\hline Income Inequality & $\begin{array}{l}0.043 \\
(0.018)^{* *}\end{array}$ & $\begin{array}{l}0.044 \\
(0.023)^{* *}\end{array}$ & $\begin{array}{l}0.065 \\
(0.031)^{* *}\end{array}$ & $\begin{array}{l}0.084 \\
(0.042)^{* *}\end{array}$ \\
\hline Democracy & & & $\begin{array}{l}0.093 \\
(0.028) * * *\end{array}$ & $\begin{array}{l}0.090 \\
(0.033)^{* * *}\end{array}$ \\
\hline Regime Durability & & & $\begin{array}{l}-0.008 \\
(0.006)\end{array}$ & $\begin{array}{l}-0.006 \\
(0.005)\end{array}$ \\
\hline Population Size & & & $\begin{array}{l}0.471 \\
(0.099)^{* * *}\end{array}$ & $\begin{array}{l}0.571 \\
(0.086) * * *\end{array}$ \\
\hline Per Capita Income & & & $\begin{array}{l}-0.006 \\
(0.141)\end{array}$ & $\begin{array}{l}0.216 \\
(0.158)\end{array}$ \\
\hline External Conflict & & & $\begin{array}{l}0.191 \\
(0.086)^{* *}\end{array}$ & $\begin{array}{l}0.241 \\
(0.106)^{* *}\end{array}$ \\
\hline Final Government Expenditure & & & $\begin{array}{l}-0.030 \\
(0.029)\end{array}$ & $\begin{array}{l}-0.041 \\
(0.030)\end{array}$ \\
\hline Estimation Technique & PPML & IV-PPML & PPML & IV-PPML \\
\hline Regional Dummies & No & No & Yes & No \\
\hline Time Dummies & No & No & Yes & Yes \\
\hline Number of Observations & 693 & 693 & 681 & 681 \\
\hline $\begin{array}{l}\text { Notes: Constant not reported. D } \\
\text { (Instrumental-variable) Instrum } \\
\text { clustered standard errors in pare }\end{array}$ & $\begin{array}{l}\text { endent vari } \\
\text { for income } \\
\text { leses. }{ }^{*} \mathrm{p}<\mathrm{C}\end{array}$ & $\begin{array}{l}=\text { Number } \\
\text { juality }=\mathrm{M} \\
{ }^{*} \mathrm{p}<0.05, *\end{array}$ & $\begin{array}{l}\text { rrorist attacks } \\
\text { cohort size. } \\
0.01 .\end{array}$ & $\begin{array}{l}V \text {-)PPML = } \\
\text { ust country- }\end{array}$ \\
\hline
\end{tabular}

Table 3: Endogeneity in the Inequality-Terrorism Nexus 


\begin{tabular}{|c|c|c|c|c|c|c|}
\hline \multicolumn{7}{|c|}{ Panel A: OLS Regression Results } \\
\hline & $(1)$ & $(2)$ & $(3)$ & $(4)$ & $(5)$ & $(6)$ \\
\hline Dependent Variable & $\begin{array}{l}\text { Tertiary } \\
\text { Schooling }\end{array}$ & $\begin{array}{l}\text { Life } \\
\text { Expectancy }\end{array}$ & $\begin{array}{l}\text { Domestic } \\
\text { Investment }\end{array}$ & $\begin{array}{l}\text { Rule of } \\
\text { Law }\end{array}$ & $\begin{array}{l}\text { Economic } \\
\text { Freedom }\end{array}$ & Corruption \\
\hline Lagged DV & $\begin{array}{l}1.056 \\
(0.018)^{* * *}\end{array}$ & $\begin{array}{l}0.985 \\
(0.007) * * *\end{array}$ & $\begin{array}{l}0.701 \\
(0.044) * * *\end{array}$ & $\begin{array}{l}0.766 \\
(0.028) * * *\end{array}$ & $\begin{array}{l}0.722 \\
(0.021)^{* * *}\end{array}$ & $\begin{array}{l}0.809 \\
(0.021) * * *\end{array}$ \\
\hline Income Inequality & $\begin{array}{l}-0.117 \\
(0.029) * * *\end{array}$ & $\begin{array}{l}-0.020 \\
(0.012) *\end{array}$ & $\begin{array}{l}-0.021 \\
(0.021)\end{array}$ & $\begin{array}{l}-0.030 \\
(0.009) * * *\end{array}$ & $\begin{array}{l}-0.015 \\
(0.005) * * *\end{array}$ & $\begin{array}{l}0.021 \\
(0.005) * * *\end{array}$ \\
\hline $\mathrm{R}^{2}$ & 0.95 & 0.98 & 0.53 & 0.77 & 0.57 & 0.77 \\
\hline Number of Observations & 494 & 610 & 589 & 610 & 610 & 610 \\
\hline \multicolumn{7}{|c|}{ Panel B: IV-OLS Regression Results } \\
\hline & $(1)$ & (2) & (4) & (4) & (5) & (6) \\
\hline Dependent Variable & $\begin{array}{l}\text { Tertiary } \\
\text { Schooling }\end{array}$ & $\begin{array}{l}\text { Life } \\
\text { Expectancy }\end{array}$ & $\begin{array}{l}\text { Domestic } \\
\text { Investment }\end{array}$ & $\begin{array}{l}\text { Rule of } \\
\text { Law }\end{array}$ & $\begin{array}{l}\text { Economic } \\
\text { Freedom }\end{array}$ & Corruption \\
\hline Lagged DV & $\begin{array}{l}1.011 \\
(0.026) * * *\end{array}$ & $\begin{array}{l}0.999 \\
(0.009) * * *\end{array}$ & $\begin{array}{l}0.705 \\
(0.040)^{* * *}\end{array}$ & $\begin{array}{l}0.774 \\
(0.035)^{* * *}\end{array}$ & $\begin{array}{l}0.648 \\
(0.026) * * *\end{array}$ & $\begin{array}{l}0.788 \\
(0.024) * * *\end{array}$ \\
\hline Income Inequality & $\begin{array}{l}-0.361 \\
(0.079) * * *\end{array}$ & $\begin{array}{l}0.012 \\
(0.017)\end{array}$ & $\begin{array}{l}-0.014 \\
(0.024)\end{array}$ & $\begin{array}{l}-0.026 \\
(0.013) *\end{array}$ & $\begin{array}{l}-0.066 \\
(0.010) * * *\end{array}$ & $\begin{array}{l}0.032 \\
(0.009) * * *\end{array}$ \\
\hline $\mathrm{R}^{2}$ & 0.95 & 0.99 & 0.53 & 0.77 & 0.51 & 0.76 \\
\hline Robust Score $\chi^{2}$ & 19.94 & 5.80 & 0.10 & 0.11 & 46.21 & 2.43 \\
\hline$\left(\right.$ Prob. $\left.>\chi^{2}\right)$ & $(0.00)^{* * *}$ & $(0.02)^{* *}$ & $(0.75)$ & $(0.74)$ & $(0.00)^{* * *}$ & $(0.12)$ \\
\hline First-Stage $F$-statistic & 54.02 & 45.98 & 104.15 & 33.70 & 93.95 & 77.32 \\
\hline (Prob. $>F)$ & $(0.00)^{* * *}$ & $(0.00)^{* * *}$ & $(0.00)^{* * *}$ & $(0.00) * * *$ & $(0.00) * * *$ & $(0.00) * * *$ \\
\hline Number of Observations & 494 & 610 & 589 & 610 & 610 & 610 \\
\hline
\end{tabular}

Table 4: Potential Transmission Channels 


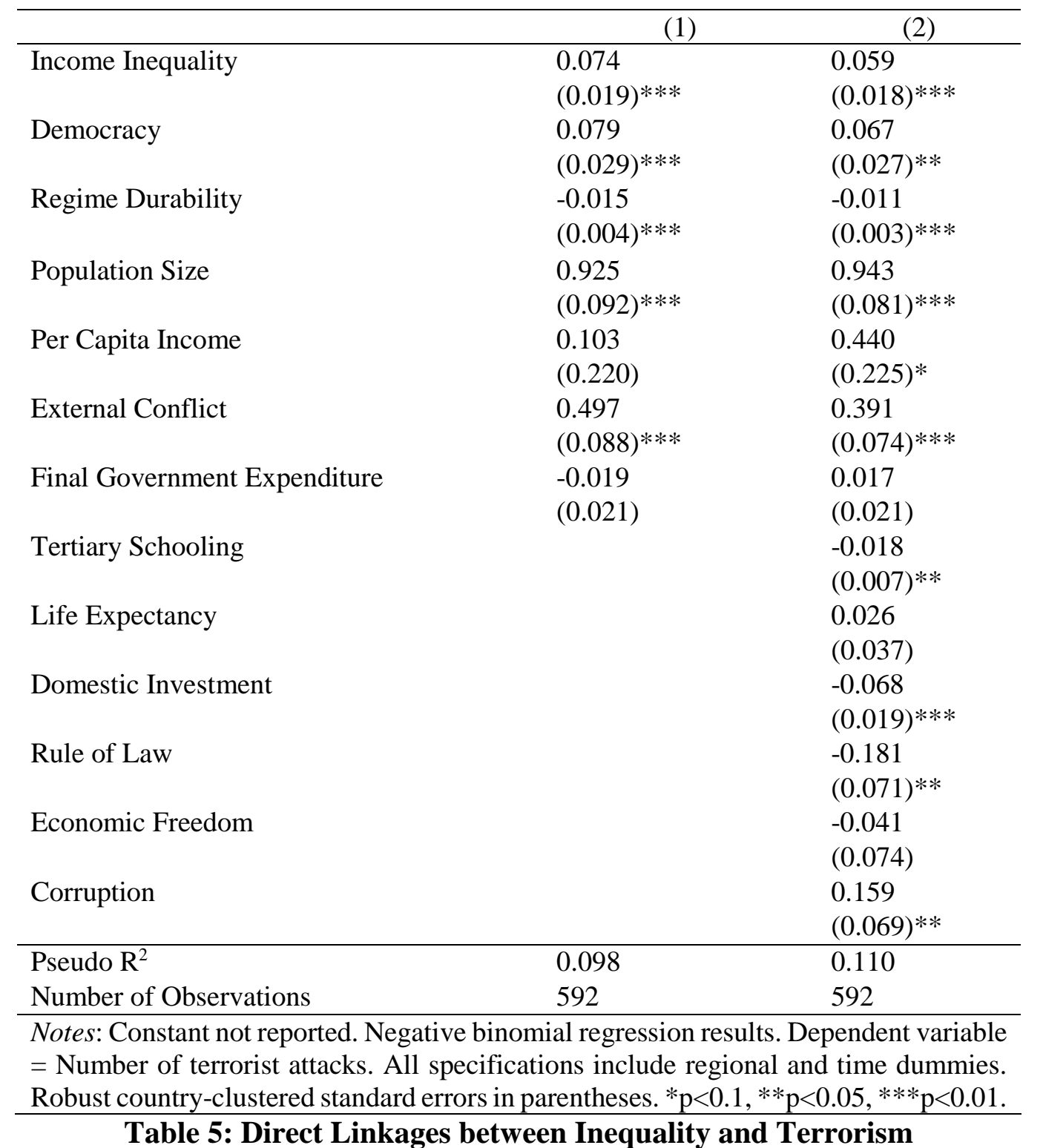




\begin{tabular}{|c|c|c|c|}
\hline & $(1)$ & $(2)$ & (3) \\
\hline Income Inequality (Net) & $\begin{array}{l}0.069 \\
(0.017)^{* * *}\end{array}$ & & \\
\hline Income Inequality (Market) & & $\begin{array}{l}0.052 \\
(0.019) * * *\end{array}$ & \\
\hline Redistribution & & & $\begin{array}{l}-1.246 \\
(0.600)^{* *}\end{array}$ \\
\hline Democracy & $\begin{array}{l}0.086 \\
(0.031)^{* * *}\end{array}$ & $\begin{array}{l}0.074 \\
(0.031)^{* *}\end{array}$ & $\begin{array}{l}0.090 \\
(0.033) * * *\end{array}$ \\
\hline Regime Durability & $\begin{array}{l}-0.009 \\
(0.005)^{*}\end{array}$ & $\begin{array}{l}-0.008 \\
(0.005)^{*}\end{array}$ & $\begin{array}{l}-0.008 \\
(0.005)\end{array}$ \\
\hline Population Size & $\begin{array}{l}0.902 \\
(0.092) * * *\end{array}$ & $\begin{array}{l}0.941 \\
(0.090)^{* * *}\end{array}$ & $\begin{array}{l}0.966 \\
(0.089)^{* * *}\end{array}$ \\
\hline Per Capita Income & $\begin{array}{l}-0.100 \\
(0.225)\end{array}$ & $\begin{array}{l}-0.163 \\
(0.238)\end{array}$ & $\begin{array}{l}0-122 \\
(0.224)\end{array}$ \\
\hline External Conflict & $\begin{array}{l}0.405 \\
(0.086) * * *\end{array}$ & $\begin{array}{l}0.413 \\
(0.091) * * *\end{array}$ & $\begin{array}{l}0.436 \\
(0.085) * * *\end{array}$ \\
\hline Final Government Expenditure & $\begin{array}{l}0.002 \\
(0.020)\end{array}$ & $\begin{array}{l}-0.008 \\
(0.021)\end{array}$ & $\begin{array}{l}0.017 \\
(0.022) \\
\end{array}$ \\
\hline Regional Dummies & Yes & Yes & Yes \\
\hline Time Dummies & Yes & Yes & Yes \\
\hline Pseudo $\mathrm{R}^{2}$ & 0.091 & 0.089 & 0.087 \\
\hline Number of Observations & 681 & 681 & 681 \\
\hline \multicolumn{4}{|c|}{$\begin{array}{l}\text { Notes: Constant not reported. Negative binomial regression results. Dependent } \\
\text { variable }=\text { Number of terrorist attacks. Robust country-clustered standard errors } \\
\text { in parentheses. }{ }^{*} \mathrm{p}<0.1,{ }^{* *} \mathrm{p}<0.05,{ }^{* * *} \mathrm{p}<0.01 \text {. }\end{array}$} \\
\hline
\end{tabular}




\section{Appendix. List of Countries}

Albania, Algeria, Angola, Argentina, Armenia, Australia, Austria, Azerbaijan, Bangladesh, Belarus, Belgium, Bolivia, Botswana, Brazil, Bulgaria, Burkina Faso, Cameroon, Canada, Chile, China, Colombia, Costa Rica, Croatia, Cyprus, Czech Republic, Denmark, Dominican Republic, Ecuador, Egypt, El Salvador, Estonia, Ethiopia, Finland, France, Gambia, Germany, Ghana, Greece, Guatemala, Guinea, Guinea-Bissau, Guyana, Haiti, Honduras, Hungary, Iceland, India, Indonesia, Iran, Ireland, Israel, Italy, Ivory Coast, Japan, Jordan, Kazakhstan, Kenya, Latvia, Lithuania, Luxembourg, Madagascar, Malawi, Malaysia, Mali, Malta, Mexico, Moldova, Mongolia, Morocco, Mozambique, Namibia, Netherlands, New Zealand, Nicaragua, Niger, Nigeria, Norway, Pakistan, Panama, Papua New Guinea, Paraguay, Peru, Philippines, Poland, Portugal, Romania, Russia, Senegal, Sierra Leone, Singapore, Slovak Republic, Slovenia, South Africa, South Korea, Spain, Sri Lanka, Sweden, Switzerland, Syria, Tanzania, Thailand, Trinidad and Tobago, Tunisia, Turkey, Uganda, Ukraine, United Kingdom, United States, Uruguay, Venezuela, Vietnam, Yemen, Zambia, Zimbabwe 


\begin{tabular}{llll}
\hline & \multicolumn{1}{c}{$(1)$} & \multicolumn{1}{c}{$(2)$} & \multicolumn{1}{c}{$(3)$} \\
\hline Income Inequality & 0.062 & 0.033 & 0.069 \\
& $(0.014)^{* * *}$ & $(0.014)^{* *}$ & $(0.017)^{* * *}$ \\
Democracy & 0.069 & -0.017 & 0.083 \\
& $(0.034)^{* *}$ & $(0.018)$ & $(0.031)^{* * *}$ \\
Regime Durability & -0.006 & -0.008 & -0.008 \\
& $(0.006)$ & $(0.004)^{* *}$ & $(0.005)^{*}$ \\
Population Size & 0.910 & 0.536 & 0.903 \\
& $(0.087)^{* * *}$ & $(0.071)^{* * *}$ & $(0.091)^{* * *}$ \\
Per Capita Income & -0.078 & -0.040 & -0.107 \\
& $(0.148)$ & $(0.111)$ & $(0.226)$ \\
External Conflict & 0.259 & 0.278 & 0.404 \\
& $(0.076)^{* * *}$ & $(0.068)^{* * *}$ & $(0.087)^{* * *}$ \\
Final Government Expenditure & 0.009 & 0.002 & 0.004 \\
& $(0.022)$ & $(0.025)$ & $(0.020)$ \\
\hline Estimation Technique & XTNBR & Probit & ZINB \\
Regional Dummies & Yes & Yes & Yes \\
Time Dummies & Yes & Yes & Yes \\
Number of Observations & 681 & 681 & 681 \\
\hline
\end{tabular}

Notes: Constant not reported. $N B R=$ Negative binomial regression. $X T N B R=$ Panel (GEE population-averaged) negative binomial regression, controlling for an AR(1) correlation structure. Probit $=$ Probit regression, where the dependent variable takes on the values 0 (no terrorism) or 1 (at least one terrorist incident). ZINB = Zero-inflated negative binomial regression. With democracy as the inflation variable. Dependent variable for XTNBR and ZINB = Number of terrorist attacks. Robust country-clustered standard errors in parentheses. ${ }^{*} \mathrm{p}<0.1$, ${ }^{* *} \mathrm{p}<0.05, * * * \mathrm{p}<0.01$.

Supplementary Table 1: Terrorism and Income Inequality (Other Estimation Methods) 